\title{
Non-Performing Loans and Its Impact on the Banking Sector: An Investigation on the Current Status of Bangladesh
}

\author{
Md. Joynal Abedin (Corresponding author) \\ Asst. Professor, Department of Finance, American International University-Bangladesh \\ 408/1, Kuratoli, Khilkhet, Dhaka 1229, Bangladesh
}

Received: September 29, 2020 Accepted: October 15, 2020 Published: October 26, 2020

doi:10.5296/jad.v6i2.17874 URL: https://doi.org/10.5296/jad.v6i2.17874

\begin{abstract}
Non-performing loans (NPLs) have become a frustrating issue for the financial institutions in Bangladesh. Our banking industry and the economy in general have taken a negative turn due to the increasing volume of NPLs. This paper aims to investigate the current status of NPLs in the banking industry of Bangladesh. The analysis uses the published data which have been congregated from the annual reports of Bangladesh Bank, websites of the scheduled banks of Bangladesh and the World Bank observed from 2008 to 2019. The study identified that for the last two decades, NPLs are the burning problems for the banks in Bangladesh. Worldwide the standard of NPLs is $2 \%$ or less but in our country, it is much intricate. The NPLs percentages in Bangladesh are 4 to 5 times higher than the standard which is disquieting for the entire banking industry. Based on the current investigation, it has been observed that the NPLs ratio is increasing unremittingly with the advancement of time. So, as a financial regulator, the central bank of the country (Bangladesh Bank) must give more emphasize to compactly control the NPLs of the country. This paper contributes by employing new dataset from Bangladesh.
\end{abstract}

Keywords: Non-performing loans, Banking sector, Bangladesh 


\section{Introduction}

The demand for a competent financial industry is essential to support and stimulate economic evolution through well-organized resource distribution. The financial industry also improves progress by pooling uncertainty and smoothing transactions. A resilient banking industry can deal with adverse sufferings and stimulate to the steadiness of the financial arrangements. In the national economy the banking industry plays a vital role by transferring the funds and mobilizing savings for constructive assets allocation. The greater it ensures, the greater the economy will flourish in the future by better high-spirited financial accomplishments and compact economic uncertainty.

In Bangladesh, the responsibility is more prominent, where banking financial institutions are the principal opportunity of stable funding in the deficiency of an established long-term market. Banking system with strong financial health safeguards efficient usage of capitals and smoothing effective distribution of resources. Access to funds by people, businesses, and other entity is difficult for starting diverse societal and corporal development endeavors, making new employments, and expanding greater efficiency. The development of banking sector is a primary need for economic expansion because of its fundamental purpose of advancing capital creation, investments and savings, as well as advancement in agricultural, industrial and services sectors. After the independence, the banking sector in Bangladesh experienced diverse challenges and difficulties due to deficiency in sufficient capital and resources. In the early1970s, authorized state-owned commercial banks along with few foreign commercial banks were permitted to channel the funds from savers to borrowers for supporting all the economic activities of the nation. This was logical as all the activities of the nation were principally compelled by the public sector participants. The central bank of Bangladesh had undertaken the complete control of both deposits and lending's rates, and majority of the funding's were channeled to state-owned entities.

After the liberation war, the banking industry journey in Bangladesh commenced with 6 state-owned commercialized (SOCBs) banks, 3 specialized banks and 9 foreign commercial banks (FCBs). In 1980's banking sectors succeeded a noteworthy development with the presence of private commercial banks (PCBs). In June 1983, two major SOCBs were privatized. The highest authority of the country also recapitalized banks, announced a fresh loan classification structure, and affordable interest rate was introduced to strengthen both money and capital markets. At the same time, FCBs were permitted to enter in the local economy and a large quantity of PCBs received license to do the businesses. By the end of 2018, there were 59 schedule banks with a total of 10,286 branches. The current banking industry encompasses four broad types of banks; 6 SOCBs, 3 state-owned development financial institutions (DFIs), 41 home-grown $\mathrm{PCBs}$, and $9 \mathrm{FCBs}$ (Annual reports of Bangladesh Bank, 2018-2019).

As of December 2018, the banking sector's total assets stood at Tk. 14,572.90 billion or around $65 \%$ of the country's GDP (Table 1). At the beginning of the country, SOCBs controlled the entire economy by providing financial supports. At present they are dwindling and far behind from the PCBs and FCBs. They are growing and reflecting higher competition 
among the banking financial institutions.

Table 1. Structure of banking system in Bangladesh, December 2018. (In billion BDT)

\begin{tabular}{|c|c|c|c|c|c|c|}
\hline $\begin{array}{l}\text { Bank } \\
\text { Types }\end{array}$ & $\begin{array}{l}\text { Number of } \\
\text { Banks }\end{array}$ & Branches & $\begin{array}{l}\text { Total } \\
\text { Assets }\end{array}$ & $\begin{array}{l}\text { Share in Industry } \\
\text { Assets (in percent) }\end{array}$ & Deposits & $\begin{array}{l}\text { Share } \\
\text { Deposits } \\
\text { (in percent) }\end{array}$ \\
\hline SOCBs & 06 & 3,746 & $3,732.20$ & 25.60 & $2,868.40$ & 26.60 \\
\hline DFIs & 03 & 1,412 & 324.00 & 2.20 & 286.00 & 2.70 \\
\hline PCBs & 41 & 5,060 & $9,769.70$ & 67.00 & $7,127.20$ & 66.00 \\
\hline FCBs & 09 & 68 & 747.10 & 5.10 & 517.10 & 4.80 \\
\hline Total & 59 & 10,286 & $14,572.90$ & 100.00 & $10,798.70$ & 100.00 \\
\hline
\end{tabular}

Source: Bangladesh Bank Annual Report 2018-2019

In January 2015, the Basel III accord was introduced to improve the banking financial institutions capital base and stimulate a sustainable financial system. At present, the minimum capital requirement (MCR) for all the scheduled banks in Bangladesh is $10.0 \%$ of risk weighted assets (RWA) or Tk 4 billion, whichever is higher. Besides this, there is a provision for capital conservation buffer, which is $2.5 \%$ of total RWA. This capital must preserve in common equity Tier 1 capital form. Beside these provisions, the banking financial institutions faces critical disputes like poor governance, lack of operational efficiency, poor financial performance, rising capital shortfalls, lack of computerization, internal risks management, lack of appropriate legal framework, inadequate credit supervising, and significant amount of NPLs, particularly in the DFIs and SOCBs although their market share is less than $30 \%$.

Many experts mentioned about NPLs issue in their study. The immediate concern of the significant amount of NPLs in the banking sector is failure of the banking financial institutions and an economic adversity. Major reasons of NPLs are mostly recognized to the inappropriate supervision and monitoring by the banks, inappropriate lenders' recourse, instability of legal framework, and the inefficient loan retrieval policies (Adhikari, 2007).

\section{Literature Review}

For the researchers, the issue of NPLs and its effect on the bank's performance are vibrant topics all over the world for a long time. A huge number of studies (Islam \& Rana, 2017; Lata, 2015; Asantey \& Tengey, 2014; Trujillo-Ponce, 2013; Pham, 2013; Shingjergji, 2013; Banker et al., 2010; Khemraj \& Pasha, 2012; Adhikary, 2006; Barseghyan, 2003; Muniappan, 2002; Altunbas et al.,2000) have been explored to find out the impact of NPLs on the banks performance throughout the world. Islam and Rana (2017) used a panel regression model for 
a six years period from 2005-2010 on Private commercial banks of Bangladesh. They revealed a noteworthy effect on return on assets (ROA) and provisions of classified loans that at the end minimize the profits. In a research, Lata (2015) has stated that increased amount of NPLs of SOCBs affected the banks' profitability adversely which in turn created massive pressure on the overall banking industry of Bangladesh. Asantey and Tengey (2014) stated that NPLs limit banks revenue which leads banks borrowings resulting in added expenditure. If a bank encounter NPLs, it negatively affects its conscientious standing and spoils forthcoming business opportunities. In a study, Adhikary (2006) mentioned that the growing amount of NPLs within the industry might not only interrupt the financial performance but also abates the credit quality of banks in Bangladesh. The author also emphasized on the maintenance of loan loss provisions and timely debt recovery actions of the banks in order to control the amount of NPLs in Bangladesh. In another study, Barseghyan (2003) revealed that if NPLs are inappropriately addressed, loans defaulter may create inverse influence on quality borrowers to delay their future repayments, and finally affect banks profitability. This problem becomes worse in an economy where recovery process is very poor. Based on the study of Munniappan (2002), banks with high NPLs have to suffer with greater carrying costs. This exerts stimulate on both capital adequacy Ratio (CAR) and profitability of a bank.

Hossain (2018) specified that NPLs in Bangladesh has become noticeable in the last few years. Organizational drawback, political will and poor governance are leading factors for the banking sector downcast. To overcome this situation, banking sector must work with structural weakness, political pressure, family traditions and governance. At the same time, central bank needs to increase its capacity so that it can ensure tight monitoring and supervision. Kingu et al. (2018) investigated the effect of NPLs on the banks performance by using asymmetric information theory and poor management hypothesis. The research establishes that existence of NPLs is inversely related with the commercial bank's profitability. Not only banks entire country's economic situation tremendously depends on NPLs.

Bashir et al. (2017) explored an empirical testing about NPLs determinants on the banking system of China. They revealed, the higher transparency in PCBs decreases NPLs, however it is not true for SOCBs. Based on their observation, unhealthy exercise in the market surges NPLs. Determinants like macroeconomic factors have a huge impact on NPLs, predominantly real GDP, inflation and real interest rate. Bank-specific factors, like bank size and profitability also have a noteworthy impact on NPLs. The study of Akter and Roy (2017) found the inverse impact of NPLs on banks profitability. Furthermore, Net Profit Margin also negatively influenced by the NPLs. The study considered 30 banks data of Bangladesh for the year 2008 to 2013. Based on the study of Balango \& Rao K. (2017) there is a noteworthy connotation between profitability and NPLs. They found significantly inverse impact of NPLs on ROA while CAR has a positive and relatively insignificant effect on ROA of commercial banks in Ethiopia. Islam \& Rana (2017) used a panel data regression model for a period of 2005 to 2010. They found NPLs and operational expenses have a substantial impact on ROA. Results also have shown that excessive NPLs may stimulate to lower financial performance due to the provisions of classified loans. Matin (2017) made a study by applying 
the feasible generalized least squares model for the period 2010-15 on 47 commercial banks of Bangladesh. They revealed that NPLs, bank size, provisions of loan loss, liquidity and cost efficiency have a noteworthy negative effect on ROA.

Though in a study Dimitrios et al. (2016) projected that loans to deposit ratio have a favorable impact on NPLs but didn't find full support of expectations. In our study, we assume that there might have inverse association between loans to deposit ratio and NPLs. Laveena and Kumar (2016) used a comparative analysis of controlling of NPLs of the Indian public and private banks. The research was grounded on the published data of ten years' time period from 2001 to 2010. They stated that the financial performance of the banks gets affected by the NPLs. Nation owned banks are more influenced by the improper management of NPLs than private banks. The study also revealed that the level of NPLs is significant in nation owned banks than private banks. They recommended that the loans granting policy of the banks should be enhanced to minimize the NPLs in the banks.

ROA is the most popular and broadly used indicators of earnings and profitability though there are numerous indicators to measure. Bhattarai (2016) has studied the impact of NPLs on the financial performance of commercial banks of Nepal and found that the NPLs ratio has an inverse influence on ROA whereas NPLs ratio has a progressive influence on Return on Equity (ROE). Kiran and Jones (2016) have examined the consequence of NPLs on the profitability of banks and found a negative association between gross NPLs and net income. Mondal (2016) used descriptive statistics and found that NPLs and interest rate spread of banks are inversely connected to each other. Chimkono et al. (2016) examined the effect of NPLs and other determinants on the profitability of Malawian commercial banks. The research stated that NPLs, lending interest rate and cost efficiency ratios had a noteworthy influence on the banks financial performance.

There are many reasons for the NPLs. But currently fund diversion, political uncertainty, unhealthy banking practices, disasters in real estate business, lack of supervising, poor harmonization between allied parties are infuriating NPLs. Appropriate and consistent monitoring, relationships among allied parties and proper execution of active laws can help to minimize the NPLs. The central bank must play a vibrant position in these alarming matters. Commercial banks of Bangladesh should confirm the transparency in conceding the credits and the central bank must confirm that the solicitation of credit granting procedures is being strictly monitored to issue a fresh loan. To decrease NPLs, appropriate measures should be taken for the retrieval of loans and new outlay must be granted to the quality borrowers. If proper recovery strategies and new investment to quality borrowers are not followed, huge volume of NPLs may diminish banks financial performance. That may carry human-created shocks in the banking sector, Alam et al. (2015).

Lata (2015) has examined a time series data and revealed that NPL is one of the key influences that stimulate banks financial performance and it has a noteworthy inverse consequence on Net Interest Income (NII) of SOCBs in Bangladesh. Nsobilla (2015) has examined the impacts of NPLs on profitability by using data of six selected rural Banks of Ghana for a time period of 2004-2013. Through OLS model, it has been observed that NPLs, 
recovered amount of loans, cost-income ratio, and total amount of revenues variables are statistically substantial on ROA. Adebisi \& Matthew (2015) in their study revealed that there is less association between the NPLs and ROA in Nigerian banks. In another study they revealed that there is a connection between the NPLs and ROE of in Nigerian banks. Hussain \& Ahamed (2015) in a research explored that NPL, NII, CAP, SIZE variables are noteworthy to explain ROA. They used the data of fifteen major PCBs in Bangladesh for a period of 2012-2016

Trujillo-Ponce (2013) revealed the association between NPLs and efficiency of commercial banks of Spain for the period of 1999-2009. The experimental results stated that NPLs have a significant inverse effect on ROA of commercial banks of Spain. Pham (2013) examined how NPLs stimulate the commercial banks of Vietnam in making profit. The study used the data from 2005-2012. It was noticed that NPLs have a significant inverse association with profitability ratio of banks. The results of the above-mentioned literatures stated multiple empirical supports regarding the effect of NPLs on the profitability of banking industry of different countries. Conferring to Shingjergji (2013), Capital Adequacy Ratio (CAR) endures an insignificant inverse correlation with NPLs. Nevertheless, the total loans and the interest margin are significantly connected with NPLs. Kaaya and Pastory (2013) studied the impact of default risk on banks' profitability by adjusting the control of bank size and deposits. The study used total eleven banks of Tanzania. Based on the correlation and regression analysis, default risk measures of NPLs, loan loss to net loans and loan loss to gross loans, have noteworthy inverse impact on banks profitability. It is proven that profitability of banks can be improved by the successful management of risk as it assists to minimize NLPs and loan losses. Sameer \& Deepa (2013) stated in their findings based on the strenuous analysis that NPLs is significantly affecting both the commercial banks and other depository institutions in expressions of their financial performance. The intentional defaulters should be identified and treated properly to recover the loans.

Shingjergji (2013) examined the influence of diverse bank specific factors on NPLs of banks in Albania by taking data from 2002 to 2012. NPLs used as a dependent variable while independent variables include capital adequacy ratio, loans to asset ratio, log of total loans, ROE and log of NII. Results obtained by applying ordinary least square regression model. The study exposed that there is an inverse insignificant association of CAR with NPLs. Correlation of loans to assets ratio has been observed inverse but total loans level is significantly manipulating the NPLs means higher loans level will result in more level of NPLs. On the other hand, NIM and ROE are negatively connected with NPLs which stimulates that significant level of NPLs deteriorate the profitability of banks. Vatansever and Hepsen (2013) investigated the existence of any significant association of NPLs with macroeconomic indicators, bank level factors and global factors for a period of 2007 to 2013 in Turkey. The study found that the factors insignificantly affects the NPLs.

Khemraj and Pasha (2009) stated that the amount of NPLs are significantly associated with banks profitability, specifically in growing economies, where NPLs rigorously affect prospective financial conditions of banks. According to Chatterjee et al. (2012) NPLs have a significant negative impact on the achievement of adequate capital level, banks credibility, 
capital employment and productivity on the economy. Based on the analysis accompanied by Dr. D. Ganesan and R. Santhanakrishnan (2013) profitability of banks can be complemented only by appropriate management of NPLs. NPLs of India has been uninterruptedly increasing for over a decade. NPLs are increasing due to improper risk management and which ultimately threatening the bank's profitability. This investigation provides suggestion that banking industry can minimize their NPLs by following the methods recommended by the central bank of respective country (Haneef \& Riaz, 2012).

Louzis et al. (2012) used bank specific factors and macroeconomic variables to examine the determinants of NPLs in the banking industry. All the selected independent variables (Total Loans, Inflation, Real GDP and Per Capita GDP) have significant impact on the depended variable (NPLs Ratio), although, values of coefficients are not much significant. Banks should tightly control and update their credit advancement strategy with respect to stated variables to have lesser NPLs ratio (Saba et al. 2012). Mohammed (2012) investigated the bank's profitability in association of corporate governance for which mainly the NLPs ratios and loans to deposits ratios have been used. The study used nine Nigerian banks for a period of 10 years from 2001 to 2010. Based on the generalized OLS regression outputs, NPLs ratio has significant inverse impact while loans to deposits ratio has insignificant inverse impact on performance. Guy (2011) stated that NPLs have been broadly used as a measure of asset quality among financial institutions and is often connected with letdowns and financial disasters in both the developed and the developing economy. Podder (2012) studied on 30 PCBs of Bangladesh for the time period of 2001-2010 and found NPLs, loans to deposits ratios, total asset, equity to total asset ratio as some foremost determinants of profitability of banks.

Banker et al., (2010) revealed that the volume of NPLs exceeding projected levels may create to lower profitability in the banking industry. The study also mentioned that the default loans minimize interest revenue, confirming that NPLs have a significant negative impact on banks profitability. Reinhart and Rogoff (2010) stated that NPLs can be used to mark the beginning of a banking crisis. Greenidge and Grosvenor (2010) revealed that the enormity of NPLs is a principal indicator in the starting and enlargement of financial crises. Lending money is not a stress-free business for banks because it shaped an immense delinquent calling NPLs (Upal, 2009).

Due to the atmosphere of their business strategy, commercial banks enlightening themselves to the consequences of default from the borrowers and NPLs are methodically associated with banking crises (Waweru and Kalami, 2009). In spite of current struggles to prevent or protect bank lending, NPLs are still a key concern for both domestic and foreign regulators (Boudriga et al, 2009). Aziz et al., (2009) revealed that the increasing of NPLs has an impact on the financial institutions. They congealed their lending and transformed their concentrations to reeducating the NPLs in their books. Hu et al. (2006) emphasized risk profile of banks where greater loans to deposits ratio could have greater NPLs.

Altunbas et al. (2000) examined the connection between the amount of NPLs and the efficiency of the commercial banks of Japan operating from 1993 to 1996. The research 
found the association between the components statistically noteworthy and positive. They suggested that banks should tightly control NPLs in order to overcome bank's efficiency.

Most of the studies have revealed the negative effect of NPLs on the bank's performance. Some research has indicated that growing NPLs in the banking industry may prejudice future business prospects of banks and wane the entire credit quality of the economy. Even, one research has suggested that poor management of NPLs and belated thump against dodged loan takers may generate negative psychological impact on quality borrowers to delay their repayments. Moreover, it is observed that the impact of NPLs on the PCBs profitability have not been appropriately explored especially for in Bangladesh. Therefore, it is meaningful to investigate the effect of NPLs on the profitability of PCBs in the circumstance of Bangladesh.

\section{Methodology}

The main aim of this study is to find out the facts and figures that are associated with NPLs in the banking sector of Bangladesh. This paper uses the sample of 59 bank's data from the year 2008 to 2019. The data has been collected from published reports of newspapers, annual reports of Bangladesh Bank, annual reports of scheduled banks, articles, journals, related books, publications from national and international research institutions, seminar papers, report of diverse financial institutions, statistics and public records. Primary data were collected from the employees of the Bangladesh Bank and schedule banks of Bangladesh.

\section{Analysis and Discussion}

Since early 2019, the government of Bangladesh has been formulating many restructuring actions to execute superior restraint within the banking and non-banking financial institutions. In this regard, the authority is revising some acts, guidelines, rules and principles for modifications, where it is a necessity. As part of this, the government is reviewing the Bangladesh Bank Order, 1972; Bank Company Act, 1991; Bankruptcy Act, 1997; Money Loan Court Act, 2003; and guidelines on mergers and acquisitions. The authority also has a plan to establish independent audit for banks to scrutinize incongruities in the industry. In the interim, the central bank announced fresh strategies on internal credit risk rating system for banks operative from $1^{\text {st }}$ of July 2019 and modified the classification of loans and provisioning regulations prolonging the loan repayment period by three months active from $30^{\text {th }}$ June 2019. Other endorsements by a six-member committee created in early 2019 including the Ministry of Finance and the central bank, included forming of an Asset Management Company (AMC), creation of secondary market for NPLs, making an independent data warehouse for NPLs under the current facilities of the CIB of the central bank, and a provision of tax rebate for managers of the NPLs that persist under contemplation. The Secured Transaction Act is also in administering, planned to be passed by the parliament in the next year, permitting debtors to use their movable assets as security with banks.

Cross-country evaluation of NPLs is challenging, as there is no undeviating definition of NPLs, and bookkeeping rules vary in different countries. But a 90-day period is broadly used by the countries to determine a loan to be NPLs. Cross-country comparison with some countries in Asia shows that the NPLs ratio to total gross loans in 2019 was highest in Cyprus 


\section{Al Macrothink}

(17.09\%), followed by Lebanon (15.19\%), Maldives (9.39\%), Russia (9.29\%), India (9.23\%), Bangladesh (8.90\%), Thailand (3.13\%), Indonesia (2.43\%), Sri Lanka (4.70\%) and Malaysia $(1.53 \%)$ (Table 2$)$. The NPLs ratio for banks in India steadily increased from $2.3 \%$ in 2010 to $9.98 \%$ in 2017, while the ratio is low in Singapore, around $1.31 \%$ of gross loans from $1.43 \%$. The NPLs ratio in Vietnam gradually declined to $1.80 \%$ in 2018 from $3.44 \%$ in 2012 . The NPLs ratio showed a declining tendency in Thailand, decreased to $2.31 \%$ until 2014 from $5.60 \%$ in 2008 , but enlarged to $3.13 \%$ by 2019 . In Malaysia, this ratio fell steadily from $4.81 \%$ in 2008 to $1.48 \%$ in 2018 . This ratio in Pakistan increased from $9.13 \%$ in 2008 to $16.21 \%$ in 2011 , and subsequently dropped up to 2018 . NPLs that created huge problems in the Republic of Korea during the financial disaster in Asia has improved considerably and stayed steady at the range of $0.5 \%-0.6 \%$ (Table 2 ).

Table 2. Bank non-performing loans to total gross loans (\%) in Asia

\begin{tabular}{|c|c|c|c|c|c|c|c|c|c|c|c|c|}
\hline Country & 2008 & 2009 & 2010 & 2011 & 2012 & 2013 & 2014 & 2015 & 2016 & 2017 & 2018 & 2019 \\
\hline Afghanistan & & & 49.90 & 4.70 & 4.96 & 4.85 & 7.78 & 12.05 & 11.07 & 12.20 & 8.89 & \\
\hline Armenia & 4.28 & 4.86 & 3.04 & 3.42 & 3.67 & 4.49 & 6.97 & 7.95 & 6.72 & 5.43 & 4.75 & 5.51 \\
\hline Bangladesh & & & & 5.85 & 9.73 & 8.64 & 9.37 & 8.40 & 8.86 & 8.90 & 9.89 & 8.90 \\
\hline Bhutan & & 6.83 & 5.20 & 3.92 & 5.44 & 6.95 & 6.75 & 6.59 & 7.19 & 8.42 & 7.03 & 8.45 \\
\hline Brunei & & 9.36 & 6.87 & 6.03 & 5.38 & 4.53 & 3.85 & 4.00 & 4.75 & 3.66 & 4.67 & 3.90 \\
\hline Cambodia & & & 3.14 & 2.29 & 2.22 & 2.30 & 1.62 & 1.59 & 2.13 & 2.07 & 1.99 & 1.55 \\
\hline China & & & 1.13 & 0.96 & 0.95 & 1.00 & 1.25 & 1.67 & 1.74 & 1.74 & 1.83 & \\
\hline Cyprus & 3.59 & 4.51 & 5.82 & 9.99 & 18.37 & 38.56 & 44.97 & 47.75 & 36.70 & 31.39 & 19.52 & 17.09 \\
\hline Georgia & 4.06 & 6.26 & 5.92 & 4.53 & 3.68 & 3.03 & 3.03 & 2.71 & 3.45 & 2.78 & 2.68 & 1.93 \\
\hline India & 2.45 & & 2.30 & 2.67 & 3.37 & 4.03 & 4.35 & 5.88 & 9.19 & 9.98 & 9.46 & 9.23 \\
\hline Indonesia & 3.19 & 3.29 & 2.53 & 2.14 & 1.77 & 1.69 & 2.07 & 2.43 & 2.90 & 2.56 & 2.29 & 2.43 \\
\hline Israel & & & & 3.42 & 3.50 & 2.86 & 2.15 & 1.84 & 1.61 & 1.29 & 1.23 & 1.39 \\
\hline Kazakhstan & 7.09 & 18.92 & 20.93 & 20.67 & 19.39 & 19.47 & 12.39 & 7.95 & 6.72 & 9.31 & 7.39 & \\
\hline Korea, Rep. & 0.57 & 0.58 & 0.59 & 0.48 & 0.59 & 0.57 & 0.49 & 0.46 & 0.47 & 0.35 & & \\
\hline
\end{tabular}




\begin{tabular}{|c|c|c|c|c|c|c|c|c|c|c|c|c|}
\hline Kuwait & 6.80 & 11.46 & 8.95 & 6.98 & 5.19 & 3.64 & 2.89 & 2.37 & 2.22 & 1.95 & 1.62 & \\
\hline Kyrgyzstan & & & 14.78 & 9.40 & 6.55 & 5.09 & 4.18 & 6.74 & 8.52 & 7.37 & 7.30 & 7.73 \\
\hline Lebanon & & & & 3.76 & 3.79 & 3.97 & 4.01 & 4.20 & 4.88 & 5.67 & 10.26 & 15.19 \\
\hline Malaysia & 4.81 & 3.63 & 3.35 & 2.68 & 2.02 & 1.85 & 1.65 & 1.61 & 1.61 & 1.55 & 1.48 & 1.53 \\
\hline Maldives & & & & & 20.92 & 17.57 & 17.48 & 14.06 & 10.63 & 10.45 & 8.90 & 9.39 \\
\hline Pakistan & 9.13 & 12.15 & 14.75 & 16.21 & 14.47 & 12.99 & 12.27 & 11.36 & 10.06 & 8.43 & 7.97 & 8.58 \\
\hline Philippines & & 3.49 & 3.38 & 2.56 & 2.22 & 2.44 & 2.02 & 1.89 & 1.72 & 1.58 & 1.67 & 1.97 \\
\hline Russia & 3.80 & 9.53 & 8.23 & 6.59 & 6.03 & 6.00 & 6.73 & 8.35 & 9.44 & 10.00 & 10.12 & 9.29 \\
\hline Saudi Arabia & & 3.29 & 2.97 & 2.22 & 1.67 & 1.31 & 1.08 & 1.24 & 1.38 & 1.61 & 1.95 & 1.86 \\
\hline Singapore & 1.43 & 2.03 & 1.41 & 1.06 & 1.04 & 0.87 & 0.76 & 0.92 & 1.22 & 1.40 & 1.31 & 1.31 \\
\hline Sri Lanka & & & & 3.82 & 3.63 & 5.58 & 4.23 & 3.24 & 2.63 & 2.50 & 3.42 & 4.70 \\
\hline Thailand & 5.60 & 5.22 & 3.89 & 2.93 & 2.43 & 2.30 & 2.31 & 2.68 & 2.99 & 3.07 & 3.08 & 3.13 \\
\hline Turkey & 3.44 & 4.97 & 3.49 & 2.58 & 2.74 & 2.64 & 2.74 & 2.99 & 3.11 & 2.84 & 3.69 & 5.02 \\
\hline UAE & & 4.18 & 5.27 & 6.09 & 7.13 & 6.66 & 5.64 & 5.03 & 5.07 & 5.30 & 5.61 & 6.46 \\
\hline Uzbekistan & & & 0.97 & 0.71 & 3.05 & 2.82 & 2.10 & 1.46 & 0.74 & 1.20 & 1.28 & 1.50 \\
\hline Vietnam & 2.15 & 1.80 & 2.09 & 2.79 & 3.44 & 3.11 & 2.94 & 2.34 & 2.28 & 1.82 & 1.80 & \\
\hline
\end{tabular}

Note. Blank cells mean data are not available.

Source: World Bank. World Development Indicators. (Retrieved from data section)

In Bangladesh the magnitude of NPLs is much greater comparing other nations in Asia. After the liberation war until 1999, there was a persistent increase in the share of NPLs, with the gross NPLs ratio to total loans in the banking industry ascending at $41.1 \%$ in 1999 . NPLs have fueled for all the banks in Bangladesh. The SOCBs and DFIs documented the maximum NPLs ratios, as they approved loans on enervated appraisal, and under directed advancing plans, predominantly in the 1970s and 1980s. After loan distributions, the banks monitoring and supervision on loans payments was not satisfactory, and such directed advancing plans 


\section{Mll Macrothink}

have steered to a huge build-up of substandard loans, resulting in prolonged huge losses. Banks were also disinclined in writing off the long-lasting default loans primarily due to lower standard associated collateral and distress of apparent legal difficulties. This also added to the proliferation of NPLs in the bank's assets portfolio.

After 1999, NPLs retrievals observed noteworthy progresses, as the NPLs ratio gradually declined to $7.3 \%$ in 2011 due to provisioning, written-off loans and a sharp drop in latest default loans. Apart from applicable regulation, greater legal powers of the banks to recover default loans through the money loan courts and better assessment of fresh loans by the CIB also enhanced. But NPLs further jump back in 2012 by $10.0 \%$, and with some oscillations, it again increased gradually, from 8.8\% in 2015 to $10.3 \%$ in 2018 (Table 3). The SOCBs and DFIs continue to record high levels of NPLs due to the employment of fresh and stricter loan classification and provisioning standard, and sanction of bulk amount of loans without much inspection and transparency.

Table 3. Gross NPLs to Total Loans by Types of Banks (In percent)

\begin{tabular}{lcccccccccccc}
\hline Bank Types & 2008 & 2009 & 2010 & 2011 & 2012 & 2013 & 2014 & 2015 & 2016 & 2017 & 2018 & 2019 \\
\hline SOCBs & 25.4 & 21.4 & 15.7 & 11.3 & 23.9 & 19.8 & 22.2 & 21.5 & 25.0 & 26.5 & 30.0 & 23.9 \\
\hline DFIs & 25.5 & 25.9 & 24.2 & 24.6 & 26.8 & 26.8 & 32.8 & 23.2 & 26.0 & 23.4 & 19.5 & 15.1 \\
\hline PCBs & 4.4 & 3.9 & 3.2 & 2.9 & 4.6 & 4.5 & 4.9 & 4.9 & 4.6 & 4.9 & 5.5 & 5.8 \\
\hline FCBs & 1.9 & 2.3 & 3.0 & 3.0 & 3.5 & 5.5 & 7.3 & 7.8 & 9.6 & 7.0 & 6.5 & 5.7 \\
\hline Total & 10.8 & 9.2 & 7.3 & 6.1 & 10.0 & 8.9 & 9.7 & 8.8 & 9.2 & 9.3 & 10.3 & 9.3 \\
\hline
\end{tabular}

Source: Department of Off-site Supervision (DOS), Bangladesh Bank.

Source: Banking Regulation and Policy Department, Bangladesh Bank.

Any abnormalities in appropriate loans administration can increase NPLs in the banking industry. The existence of an afflicting volume of NPLs leads to unfavorable impacts for banks, comprising the following:

NPLs confines fresh advancing competence. Unless funds lent out is retrieved within appropriate time, it will not be accessible to make new loans. When the shortcomings become dominant in the banking industry, the financial structure becomes incompetent to offer fresh loans. This effects in slowdown of an economy.

Growing volume of NPLs require banks to increase provisions against probable loan losses and carry out internal associations to progress asset quality, including writing-off loans. The resulting reduction in credit payments leads to a lower ROA and ROA, affecting soundness and liquidity of banks. 


\section{MInstitute ${ }^{\text {Mink }}$}

The performance of a bank can be determined by the bank manager's risk-taking comportment. Banks with extreme NPLs cannot take risk due to poor financial performance. Funding costs also increase, as counterparties pursue to cover the uncertainties of lending to destabilized banks.

Mostly, the excessive NPLs ratio dwindles the overall credit eminence of the banking industry in Bangladesh. For the general public, banks act as custodians of the deposits and facilitate monetary activities, such as mobilization of savings both in the public and private sectors, production and circulations, and deficiency reduction. It is thus important to execute adequate measures to properly address the current glitches of default loans.

The decision of lending for a bank is vital because it outlines the banks future performance. In recent times banks are becoming more cognizant about customer selection to minimize or avoid the inverse impact of NPLs. Amounts of default loans are threateningly growing in not only the developing and underdeveloped nations but also in advanced countries. Banks granting policy of loans could have very significant impact on NPLs. Rajesh Parmer (2014) stated that managing NPLs is a challenging job for every bank in the financial system. NPLs affect the performance and then position of the banks in various magnitudes.

Banks financial health is predominantly influenced by the rise of NPLs. As per the guideline of Bangladesh Bank, banks are needed to provide $1.00 \%$ of the loans as expenses under the head 'provision'. If the loans fall under 'sub-standard' classification due to non-performance of the loans, then banks are needed to maintain $20.0 \%$ provision. But If the loans are 'Doubtful', then the provision is $50.00 \%$ and for 'bad and loss' classification, $100.00 \%$ provision is compulsory. Thus, the massive volume of provisioning against earnings reduces the bank's profitability. Finally, this decline of net profit badly influences the shareholder's equity. As a result, a decline in the banks' ability of dividend paying.

Table 4. Profitability Ratios (ROA) by Types of Banks (In percent)

\begin{tabular}{lcccccccccccc}
\hline Bank Types & 2008 & 2009 & 2010 & 2011 & 2012 & 2013 & 2014 & 2015 & 2016 & 2017 & 2018 & 2019 \\
\hline SOCBs & 0.7 & 1.0 & 1.1 & 1.3 & -0.56 & 0.59 & -0.55 & -0.04 & -0.16 & 0.21 & -1.30 & -0.6 \\
\hline DFIs & -0.6 & 0.4 & 0.2 & 0.1 & 0.06 & 0.40 & -0.68 & -1.15 & -2.80 & -0.62 & -2.77 & -3.3 \\
\hline PCBs & 1.4 & 1.6 & 1.6 & 1.6 & 0.92 & 0.95 & 0.99 & 1.00 & 1.03 & 0.89 & 0.79 & 0.8 \\
\hline FCBs & 2.9 & 3.2 & 3.2 & 3.2 & 3.27 & 2.98 & 3.38 & 2.92 & 2.56 & 2.24 & 2.23 & 2.3 \\
\hline Total & 1.2 & 1.4 & 1.5 & 1.5 & 0.64 & 0.90 & 0.64 & 0.90 & 0.68 & 0.74 & 0.25 & 0.4 \\
\hline
\end{tabular}

Source: Department of Off-site Supervision (DOS), Bangladesh Bank. 


\begin{tabular}{lccccccccccccc} 
Table & 5. & \multicolumn{1}{c}{ Profitability } & Ratios & $(\mathrm{ROE})$ & by & Types & of & Banks & (In & percent $)$ \\
\hline $\begin{array}{l}\text { Bank } \\
\text { Types }\end{array}$ & 2008 & 2009 & 2010 & 2011 & 2012 & 2013 & 2014 & 2015 & 2016 & 2017 & 2018 & 2019 \\
\hline SOCBs & 22.5 & 26.2 & 18.4 & 19.7 & -11.87 & 10.93 & -13.46 & -1.47 & -6.02 & 3.45 & -29.61 & -13.7 \\
\hline DFIs & -6.9 & -171.7 & -3.2 & -0.9 & -1.06 & -5.81 & -5.97 & -5.79 & -13.88 & -3.07 & -13.47 & -17.0 \\
\hline PCBs & 16.4 & 21.0 & 20.9 & 15.7 & 10.17 & 9.76 & 10.26 & 10.75 & 11.09 & 12.01 & 10.98 & 11.2 \\
\hline FCBs & 17.8 & 22.4 & 17.0 & 16.6 & 17.29 & 16.93 & 17.67 & 14.59 & 13.08 & 11.31 & 12.42 & 13.4 \\
\hline Total & 15.6 & 21.7 & 21.0 & 17.0 & 8.20 & 11.10 & 8.09 & 10.51 & 9.42 & 10.60 & 3.86 & 6.8 \\
\hline
\end{tabular}

Source: Department of Off-site Supervision (DOS), Bangladesh Bank.

Earnings or profitability as measured by ROA and ROE differ among the bank types. Table 4 and 5 shows ROA and ROE of four broad types of banks from 2010 to 2019. Investigation of these indicators discloses that the ROA of the SOCBs and DFIs were less than the industry average. The ROA of SOCBs further declined in 2018. On the other hand, after showing an increasing inclination from 2012 to 2016 , ROA of PCBs has steadily decreased in the past years. Though ROA of FCBs showed a declining movement from 2014 to 2018 but it always remained in a sturdy position. ROA of the banking industry raised at $0.30 \%$ at the end of December 2019. Table 5 presents that ROE of the SOCBs raised at $-13.70 \%$ in 2019 . It has significantly fallen in 2019 as compared to 2018. ROE of DFIs also dropped to negative $17.00 \%$. ROE of PCBs declined to $11.20 \%$ in 2019. ROE of FCBs has decreased since 2014 but in 2018, it increased to $12.42 \%$ and in 2019 it increased to $13.40 \%$. ROE of the banking industry raised at $6.80 \%$ at the end of December 2019. More details of profitability for all banks are given in Table 4 and Table 5.

When a loan turns into non-performing, it initiates a noteworthy effect on the liquidity. Due to non-recovery of repayments, the prearranged cash managements are directly affected. Majority of financial institutions, especially banks are largely dependent on these loan repayments for their forthcoming investment, meeting operational expenditure and also to pay off the debts in time. Due to poor repayments of granted loans, banks are required to arrange short-term loans from possible sources which again, surges the expenditure having an inverse effect on banks financial performance or profitability. 
Table 6. Liquidity Ratio by Types of Banks (In percent)

\begin{tabular}{lcccccccccccc}
\hline Bank Types & 2008 & 2009 & 2010 & 2011 & 2012 & 2013 & 2014 & 2015 & 2016 & 2017 & 2018 & June 2019 \\
\hline SOCBs & 32.9 & 25.1 & 27.2 & 31.3 & 29.2 & 44.3 & 42.0 & 41.4 & 40.0 & 30.4 & 24.8 & 26.6 \\
\hline DFIs & 13.7 & 9.6 & 21.3 & 6.9 & 12.0 & 15.3 & 6.6 & 0.0 & 0.0 & 0.0 & 0.0 & 0.0 \\
\hline PCBs & 20.7 & 18.2 & 21.5 & 23.5 & 26.3 & 28.0 & 28.2 & 19.7 & 17.8 & 14.8 & 14.2 & 15.1 \\
\hline FCBs & 31.3 & 31.8 & 32.1 & 34.1 & 37.5 & 46.2 & 56.9 & 51.8 & 48.2 & 43.8 & 48.4 & 36.3 \\
\hline Total & 24.8 & 20.6 & 23.0 & 25.4 & 27.1 & 32.5 & 32.7 & 26.5 & 24.9 & 19.9 & 18.2 & 18.7 \\
\hline
\end{tabular}

Source: Department of Off-site Supervision (DOS), Bangladesh Bank.

Appropriate liquidity management benefits to ensure bank's capability to meet cash flow requirements, which are ambiguous as they are exaggerated by peripheral activities and behavior other party. Indicators like statutory liquidity ratio (SLR), advance-deposit ratio, interbank call money rate, and repurchase agreement rate show the perfect picture of banking sector liquidity. Moreover, one can assess bank's capability to survive against any liquidity crises through the liquidity coverage ratio and net stable funding ratio by considering a hypothetical consequence.

All scheduled banks required a Cash Reserve Ratio (CRR) averaging 4.0\% daily on a biweekly basis in contrast to average total demand and time liabilities (ATDTL) of the second preceding month, with a requirement to maintain daily minimum $3.5 \%$ cash against the same ATDTL held by the bank. The current rate of SLR for conventional banks is $13.0 \%$ of ATDTL. In case of Islamic Shariah based banks, the rate of SLR is $5.5 \%$ of their ATDTL (Bangladesh Bank Monetary Policy FY, 2020-2021; MPD Circular No. 03: Change of Cash Reserve Ratio (CRR)). Specialized banks are exempted from the maintenance of SLR, but these banks have to maintain CRR at the same rate as other scheduled banks are maintaining. Banks maintain CRR with Bangladesh Bank in cash. The CRR was reduced from 5.5\% to 5\% on 1st of April 2020. The CRR was cut further to 4\% on 15th of April 2020. The cut in CRR is expected to free up Tk. 171.0 billion in liquidity for the banking sector. The total liquidity ratio for all types of bank at the end of June 2019 was $18.70 \%$. SOCBs maintained a maximum liquidity ratio of $26.60 \%$ (Table 6).

Capital adequacy is the minimum amount of capital a bank or any financial institution has to hold as mandatory by its financial regulator in order to tackle the potential risks and prevent the financial institution's debt holder. Under Basel-III accord, Banks are bound to maintain MCR at $10.0 \%$ of Risk-Weighted Assets or Tk. 5.0 billion as capital whichever is higher. Capital adequacy focuses on the total position of bank's capital and the fortification of 
depositors and other creditors from the future risks that a bank might suffer. It helps to minimize potential uncertainty due to credit, market and operational risks that a bank might be encountered during its regular activities.

Table 7 shows the Capital to Risk Weighted Assets Ratio (CRAR) by type of banks. It is observed that the CRAR of SOCBs, PCBs and FCBs, on 31st December 2019, were 5.0\%, $13.6 \%$ and $24.5 \%$ respectively. Both the DFIs failed to maintain MCR on RWA basis. Besides, few SOCBs could not maintain the minimum required CRAR. The CRAR of the banking industry as a whole was $11.6 \%$ at the end of December 2019 as against $12.06 \%$ at the end of December 2018. The CRAR of the banking sector was $11.6 \%$ at the end of December 2019 (Table 7).

Table 7. Capital to Risk Weighted Assets Ratio by Types of Banks (In percent)

\begin{tabular}{lcccccccccccc}
\hline $\begin{array}{l}\text { Bank } \\
\text { Types }\end{array}$ & 2008 & 2009 & 2010 & 2011 & 2012 & 2013 & 2014 & 2015 & 2016 & 2017 & 2018 & 2019 \\
\hline SOCBs & 6.9 & 9.0 & 8.9 & 11.68 & 8.31 & 10.81 & 8.26 & 6.35 & 5.86 & 5.04 & 10.34 & 5.0 \\
\hline DFIs & -5.3 & 0.4 & -7.3 & -4.49 & -7.78 & -9.65 & -17.35 & -31.95 & -33.67 & -35.45 & -31.74 & -32.0 \\
\hline PCBs & 11.4 & 12.1 & 10.1 & 11.49 & 11.38 & 12.52 & 12.54 & 12.38 & 12.36 & 12.52 & 12.80 & 13.6 \\
\hline FCBs & 24.0 & 28.1 & 15.6 & 20.97 & 20.56 & 20.27 & 22.67 & 25.60 & 25.37 & 24.90 & 25.92 & 24.5 \\
\hline Total & 10.1 & 11.6 & 9.3 & 11.35 & 10.46 & 11.52 & 11.35 & 10.84 & 10.80 & 10.83 & 12.06 & 11.6 \\
\hline
\end{tabular}

Source: Department of Off-site Supervision (DOS), Bangladesh Bank.

Source: Banking Regulation and Policy Department, Bangladesh Bank.

\section{Conclusion}

Default Loans has instigated a negative influence on the growth of Banking Business. It should be mentioned here that our SOCBs and some PCBs are also facing capital shortages due to the non-payment of a large number of borrowers. In the case of public banks, the capital gap has been filled with public money. The government has spent huge amount of money over the past decade to recapitalize dying state banks. The banking industry needs stronger lending and enforcement policies to tackle credit problems. The Bangladesh Bank must be empowered to take instant initiatives to tackle the NPLs crisis. Bangladesh should enrich its database and provide details on overdue lenders, which can then serve as a filter factor in the client selection process. Basically, government commitment and strict compliance can minimize NPLs. Reforms to the current bank management system, SOCBs reform, the creation of a dedicated banking tribunal, and a policy framework to truly identify 
unintentional and willful defaulters can be an appropriate strategy to tackle the threat.

\section{References}

Adebisi, J. F., \& Matthew, O. B. (2015). The impact of non-performing loans on firm profitability: a focus on the Nigerian banking industry. American Research Journal of Business and Management, 1(4), 1-7.

Adhikary, B. K. (2006). Nonperforming loans in the banking sector of Bangladesh: realities and challenges. Bangladesh Institute of Bank Management, 4(26), 75-95.

Akter, R., \& Roy, J. K. (2017). The impacts of non-performing loan on profitability: An empirical study on banking sector of Dhaka stock exchange. International Journal of Economics and Finance, 9(3), 126-132. https://doi.org/10.5539/ijef.v9n3p126

Alam, S., Haq, M. M., \& Kader, A. (2015). Nonperforming loan and banking sustainability: Bangladesh perspective. International Journal of Advanced Research, 3(8), 1197-1210.

Altunbas, Y., Liu, M. H., Molyneux, P., \& Seth, R. (2000). Efficiency and risk in Japanese banking. Journal of Banking \& Finance, 24(10), 1605-1628. https://doi.org/10.1016/S0378-4266(99)00095-3

Asantey, J. O., \& Tengey, S. (2014). An empirical study on the effect of Bad Loans on banks' lending potential and financial performance: The case of SMEs lending in Ghana. International Journal of Research in Business Management, 2(11), 1-12.

Abdul Aziz, N. F., \& Ibrahim, I. (2008). The impact of Non-performing Loans (NPL) towards profitability performance (ROA, ROE, \& NPM).

Balango, T. K., \& Rao, M. (2017). The effect of NPL on profitability of banks with reference to commercial bank of Ethiopia. Business and Management Research Journal, 7(5), 45-50.

Banker, R. D., Chang, H., \& Lee, S. Y. (2010). Differential impact of Korean banking system reforms on bank productivity. Journal of Banking \& Finance, 34(7), 1450-1460. https://doi.org/10.1016/j.jbankfin.2010.02.023

Bashir, U., Yu, Y., Hussain, M., Wang, X., \& Ali, A. (2017). Do banking system transparency and competition affect nonperforming loans in the Chinese banking sector?. Applied Economics Letters, 24(21), 1519-1525. https://doi.org/10.1080/13504851.2017.1305082

Barseghyan, L. (2003). Non Performing Loans, Prospective Bailouts, and Japan's Slowdown. Northwestern University.

Bhattarai, Y. R. (2016). Effect of non-performing loan on the profitability of commercial banks in Nepal. Prestige International Journal of Management and Research, 1-9.

Boudriga, A., Taktak, N. B., \& Jellouli, S. (2009). Banking supervision and nonperforming loans: a cross-country analysis. Journal of financial economic policy. https://doi.org/10.1108/17576380911050043

Chatterjee, C., Mukherjee, J., \& Das, R. (2012). Management of nonperforming assets-a 
current scenario. International Journal of Social Science \& Interdisciplinary Research, 1(11), 204-214.

Chimkono, E. E., Muturi, W., \& Njeru, A. (2016). Effect of non-performing loans and other factors on performance of commercial banks in Malawi. International Journal of Economics, Commerce and Management, 4(2), 549-563.

Dimitrios, A., Helen, L., \& Mike, T. (2016). Determinants of non-performing loans: Evidence from Euro-area countries. Finance research letters, 18, 116-119. https://doi.org/10.1016/j.frl.2016.04.008

Ganesan, D., \& Santhanakrishnan, R. (2013). Non-performing assets: a study of State Bank of India. Retrieved from Asia Pacific Journal Of Research, 1.

Greenidge, K., \& Grosvenor, T. (2010). FORECASTING NON-PERFORMING LOANS IN BARBADOS. Journal of Business, Finance \& Economics in Emerging Economies, 5(1).

Guy, K. (2011). Non-performing loans. Economic Review, 32(1), 7-9.

Haneef, S., Riaz, T., Ramzan, M., Rana, M. A., Hafiz, M. I., \& Karim, Y. (2012). Impact of risk management on non-performing loans and profitability of banking sector of Pakistan. International Journal of Business and Social Science, 3(7).

Hossain, M. S., \& Ahamed, F. (2015). Determinants of bank profitability: A study on the banking sector of Bangladesh. Journal of Finance and Banking, 13(1), 43-57.

Hossain, M. T. (2018). The trend of default loans in Bangladesh: Way forward and challenges. International Journal of Research in Business Studies and Management, 5(6), 24-30.

Hu, J., Yang, L., \& Yung-Ho, C. (2006). Ownership and Nonperforming Loans: Evidence from Taiwan's Banks. Developing Economies. Forthcoming at the reference paper.

Islam, M. A., \& Rana, R. H. (2017). Determinants of bank profitability for the selected private commercial banks in Bangladesh: A panel data analysis. Banks \& bank systems, (12,№ 3 (cont.)), 179-192.

Kaaya, I., \& Pastory, D. (2013). Credit risk and commercial banks performance in Tanzania: A panel data analysis.

Khemraj, T., \& Pasha, S. (2009). The determinants of non-performing loans: an econometric case study of Guyana.

Kingu, P. S., Macha, S., \& Gwahula, R. (2018). Impact of non-performing loans on bank's profitability: Empirical evidence from commercial banks in Tanzania. International Journal of Scientific Research and Management, 6(01). https://doi.org/10.18535/ijsrm/v6il.em11

Kiran, K. P., \& Jones, T. M. (2016). Effect of Non Performing Assets On The Profitability of Banks-A Selective study. International Journal of Business and General Management, 5(2), 53-60.

Lata, R. S. (2015). Non-performing loan and profitability: The case of state owned 
commercial banks in Bangladesh. World Review of Business Research, 5(3), 171-182.

Laveena, \& Kumar, H. (2016). Management of non-performing assets on profitability of public and private sectors banks. International Journal of Research in Management \& Technology, 6(2), 86-93.

Louzis, D. P., Vouldis, A. T., \& Metaxas, V. L. (2012). Macroeconomic and bank-specific determinants of non-performing loans in Greece: A comparative study of mortgage, business and consumer loan portfolios. Journal of Banking \& Finance, 36(4), 1012-1027. https://doi.org/10.1016/j.jbankfin.2011.10.012

Mohammed, F. (2012). Impact of corporate governance on banks performance in Nigeria. Journal of Emerging Trends in Economics and Management Sciences, 3(3), 257-260.

Mondal, T. (2016). Sensitivity of non-performing loan to macroeconomic variables: empirical evidence from banking industry of Bangladesh. Global Journal of Management and Business Research.

Muniappan, G. P. (2002). The NPA Overhang-Magnitude, Solutions, Legal Reforms. Reserve Bank of India Bulletin, 18-19.

NSOBILLA, T. (2016). The effect of non-performing loans on the financial performance of selected rural banks in the Western and Ashanti regions of Ghana (Doctoral dissertation).

Phạm, T. (2013). Effect of bad debts on bank profitability. Economic Research, 424, 34-39.

Trujillo-Ponce, A. (2013). What determines the profitability of banks? Evidence from Spain. Accounting \& Finance, 53(2), 561-586. https://doi.org/10.1111/j.1467-629X.2011.00466.x

Reinhart, C. M., \& Rogoff, K. S. (2011). From financial crash to debt crisis. American Economic Review, 101(5), 1676-1706. https://doi.org/10.1257/aer.101.5.1676

Saba, I., Kouser, R., \& Azeem, M. (2012). Determinants of non performing loans: Case of US banking sector. The Romanian Economic Journal, 44(6), 125-136.

Samir, D., \& Kamra, D. (2013). A comparative analysis of non-performing assets (NPAs) of selected commercial banks in india. Opinion: International Journal of Management, 3(1).

Shingjergji, A. (2013). The impact of bank specific variables on the non performing loans ratio in the Albanian banking system. Research Journal of Finance and Accounting, 4(7), $148-152$.

Uppal, R. K. (2009). Priority sector advances: Trends, issues and strategies. Journal of accounting and taxation, 1(5), 079-089. https://doi.org/10.5897/JAT09.022

Vatansever, M., \& Hepsen, A. (2013). Determining impacts on non-performing loan ratio in Turkey. Journal of Finance and Investment Analysis, 2(4), 119-129.

Waweru, N. M. Kalani. VM (2009). Commercial banking crises in Kenya: Causes and remedies. Global journal of finance and Banking issues, 3(3), 15-20. 


\section{Copyright Disclaimer}

Copyright for this article is retained by the author(s), with first publication rights granted to the journal.

This is an open-access article distributed under the terms and conditions of the Creative Commons Attribution license (http://creativecommons.org/licenses/by/4.0/). 